\title{
ANALISIS PROFITABILITAS PRODUK UNTUK MENGUKUR KINERJA PEMASARAN UKM KONVEKSI ROCKAFELLA DAN MAULIDHA 77, PURWAKARTA
}

\author{
Tresna Wulandari, Rahmawaty Arifiani
}

Article Information

Received: 28 Nov. 2019

Accepted: 19 Mar. 2020

Published: 18 Apr. 2020

DOI 10.33555/ijembm.v6i2.114

Corresponding Author:

Tresna Wulandari

Politeknik Perdana Mandiri -

Purwakarta

tresna.wulandari@gmail.com

ISSN 2338-8854 eISSN 2620-9918

\begin{abstract}
The result of product sales of Rockafella and Maulidha 77 tended to fluctuative in 2018. Meanwhile, sales volume will affect on the contribution of marketing mix program to profitability value. The product profitability analysis enables for venture owner to evaluate performance and identify the issue of marketing program. This study applied qualitative method. This study population is social situation consisting of three elements; places, actors, and activities. This study applied purposive sampling technique where the selected data source sample is the owner of the Rockafella and Maulidha 77. They were considered as the most knowledgeable of the marketing performance analysis. The variables that influence the difference in value based on financial aspects are sales volume, equity, and assets. And based on the marketing aspect are affected product line and quality, price, distribution, promotion, facilities, and services.
\end{abstract}

Keywords: Product Profitability, PVCM, Marketing Performance

\begin{abstract}
ABSTRAK
Hasil penjualan produk Rockafella dan Maulidha 77 cenderung berfluktuasi pada tahun 2018. Sementara itu, volume penjualan akan mempengaruhi kontribusi program bauran pemasaran terhadap nilai profitabilitas. Analisis profitabilitas produk memungkinkan pemilik usaha untuk mengevaluasi kinerja dan mengidentifikasi masalah program pemasaran. Penelitian ini menggunakan metode kualitatif. Populasi penelitian ini adalah situasi sosial yang terdiri dari tiga elemen; tempat, aktor, dan kegiatan. Penelitian ini menggunakan teknik purposive sampling dimana sampel sumber data yang dipilih adalah pemilik Rockafella dan Maulidha 77. Mereka dianggap sebagai yang paling berpengetahuan luas dari analisis kinerja pemasaran. Variabel-variabel yang mempengaruhi perbedaan nilai berdasarkan aspek keuangan adalah volume penjualan, ekuitas, dan aset. Dan berdasarkan aspek pemasaran dipengaruhi lini produk dan kualitas, harga, distribusi, promosi, fasilitas, dan layanan.
\end{abstract}

Keywords: Profitabilitas Produk, PVCM, Kinerja Pemasaran 


\section{Pendahuluan}

Dinas Koperasi dan Usaha Mikro Kecil Menengah (KUMKM) Provinsi Jawa Barat menargetkan dapat mencetak 20.000 wirausahawan baru atau pelaku UMKM di Jawa Barat pada tahun 2017. Sekitar 3.000 UMKM dari jumlah tersebut, mayoritas berasal dari tiga jenis usaha yang fokus digarap, yaitu kuliner (makanan dan minuman), konveksi pakaian, dan salon kecantikan. Guna mewujudkan target itu, Dinas KUMKM Jabar akan memberikan pembinaan dan pelatihan wirausaha bagi ribuan calon wirausahawan baru tersebut (Dudi Sudrajat Abdurachim, Kepala Dinas KUMKM Jabar pada jabar.tribunnews.com). Usaha konveksi dapat didefinisikan sebagai industri kecil skala rumah tangga yang melayani pembuatan pakaian jadi secara masal dalam jumlah banyak. Model pakaian yang diproduksi biasanya berupa kaus, kemeja, celana, jaket, jas almamater, busana muslim, dan sebagainya, yang dipesan berdasarkan ukuran standar yang telah ditentukan. Karena produk yang dihasilkan oleh industri konveksi termasuk ke dalam salah satu kebutuhan dasar manusia, kepopuleran bisnis konveksi ini diprediksi akan terus meningkat. Didukung oleh permintaan pasar yang begitu besar, peluang untuk memulai dan mengembangkan usaha konveksi juga dirasa sangat besar.

Beberapa jenis usaha konveksi diantaranya pakaian anak-anak, topi, kerudung, dan konveksi kaos gaul. Usaha konveksi mirip dengan industri garmen, Namun menurut pendapat beberapa pengusaha, usaha konveksi sedikit berbeda dengan usaha garmen. Masingmasing kelompok kerja pada usaha garmen (contohnya pakaian kerja/kantor) mengerjakan sub bagian tertentu, ada tim kerja yang khusus membuat kerah, mengukur dan memotong kain, menjahit (merakit) dan ada kelompok yang khusus bertugas pada bagian akhir (merapikan/ menyeterika). Sedangkan pada usaha konveksi, setiap orang (tim) bertugas menyelesaikan secara menyeluruh yang dikenal dengan istilah CMT (Cutting, Making, Trimming), yaitu mulai dari memotong atau mengukur, membuat, dan merapikan.

Sudut pandang yang menjadi hal pokok memulai usaha garmen/konveksi adalah 4P, yaitu Place, Product, Price, dan Promotion, yang dikenal dengan istilah bauran pemasaran. Diawali dari tempat yang strategis dengan memusatkan pilihan pada tempat yang memungkinkan lebih banyak dikunjungi orang. Selanjutnya menganalisa mutu dari produk yang akan dijual juga menjadi bagian pemikiran yang kompleks.

Selain itu, terdapat harga yang lebih ekonomis dan dapat bersaing demi pangsa pasar yang luas. Terakhir adalah promosi luas yang luar biasa akan berdampak terhadap minat dan menarik para calon konsumen.

Hingga saat ini, bisnis konveksi masih sangat diminati. Bisnis ini mampu bertahan di berbagai kondisi. Pakaian merupakan kebutuhan pokok manusia, sehingga bisnis ini selalu dapat diandalkan. Mengingat permintaan pasar terhadap kebutuhan pakaian relatif stabil, bisnis konveksi menawarkan keuntungan yang potensial. Melalui dukungan teknologi saat ini, distribusi produk konveksi pun menjadi semakin mudah, salah satunya melalui bisnis online. Fakta tersebut membuat peluang bisnis konveksi makin berkembang. Bersumber pada media online dan hasil survey, terdapat 42 bisnis konveksi di Kabupaten Purwakarta, 20 diantaranya berada di Kecamatan Purwakarta, sisanya tersebar di Kecamatan Jatiluhur, Babakancikao, Bungursari, Plered, Pasawahan, dan Kecamatan Campaka. Berdasarkan data di atas, terlihat tingkat persaingan cukup tinggi di antara bisnis konveksi di Kabupaten Purwakarta. Agar tetap bertahan dalam persaingan, selain setiap pengusaha konveksi harus memperhatikan 
aspek strategi, taktik, dan value pemasarannya, diperlukan pula mengevaluasi performa atau kinerja pemasarannya.

Menurut Nurhayani dan Suryano (2019), "Kinerja pemasaran merupakan dampak dari hasil strategi pemasaran yang dilakukan oleh suatu perusahaan. Pengukuran kinerja pemasaran akan menjadi faktor yang penting karena dapat digunakan sebagai evaluasi dan tolak ukur bagi kegiatan pemasaran". Cannon, et.al (2009) menambahkan, "Tujuan dari analisis kinerja adalah untuk memperbaiki operasi, tenaga penjualan, teritori, atau faktor-faktor lain yang menunjukkan kinerja yang buruk dapat diidentifikasi dan dipilah untuk analisis yang rinci dan mendapatkan tindakan perbaikan". Berbagai kalangan, baik praktisi maupun akademisi, kerap melontarkan kritik bahwa pemasaran dianggap telah mencapai titik overspent dan underdelivered dikarenakan sulitnya mengukur efektivitas dan efisiensi setiap aktivitas, keputusan, atau program pemasaran. Belum lagi ada kenyataan bahwa semakin banyak tugas pemasaran yang juga dilakukan oleh fungsi bisnis lainnya. Oleh sebab itu, dibutuhkan analisis kinerja pemasaran yang lebih obyektif dan terfokus dalam rangka menilai profitabilitas dan produktivitas keputusan pemasaran (Tjiptono dkk, 2008).

Kinerja dapat diketahui dengan menganalisis faktor-faktor yang bersifat tangible dan intangible. Faktor-faktor yang bersifat tangible adalah profitabilitas, market share, biaya produksi, rencana pengembangan produk baru, dan sebagainya. Abdurrahman (Nurhayani dan Suryano; 2019) mengungkapkan beberapa cara mengukur kinerja bisnis yaitu dengan ROI, value added, market share, dan marketing metrics. Marketing metrics dapat mengukur secara financial metrics dan nonfinancial metrics. Pengukuran dengan menggunakan financial metrics salah satunya adalah menghitung bagaimana profitabilitas dan biaya pemasaran yang digunakan.

Variabel penelitian ini dibatasi pada faktor profitabilitas sebagai salah satu financial marketing metrics, khususnya profitabilitas produk Tjiptono, dkk (2008) mengungkapkan, "Analisis profitabilitas adalah penilaian yang dilakukan untuk menelaah pengaruh dari berbagai strategi dan program pemasaran terhadap kontribusi laba yang dapat diharapkan dari produk atau lini produk tertentu.Analisis semacam ini sangat penting bagi para manajer pemasaran". Peran profitabilitas diungkapkan Pearce dan Robinson (2008), "Profitabilitas merupakan tujuan tetap dari suatu organisasi bisnis. Tanpa memperhatikan bagaimana laba diukur atau didefinisikan, laba jangka panjang merupakan indikasi yang paling jelas dari kemampuan perusahaan untuk memenuhi klaim serta keinginan utama dari karyawan dan pemegang saham. Pertumbuhan suatu perusahaan sangat terikat dengan kelangsungan bisnis serta profitabilitasnya".

Aspek penting dari manajemen adalah penelaahan profitabilitas produk secara rutin. Penelaahan ini seharusnya diarahkan pada isu-isu: 1) produk mana yang paling menguntungkan?; 2) apakah harga jual ditentukan dengan tepat?; 3) produk mana yang seharusnya dipromosikan dan diiklankan paling gencar?; dan 4) manajer produk mana yang patut diberi penghargaan? (Blocher, et.al, 2007). Adapun pendekatan atau ukuran yang digunakan dalam analisis profitabilitas produk pada penelitian ini adalah margin kontibusi.

Blocher, et.al (2007) mengungkapkan, "Ukuran terbaik atas tingkat profitabilitas jangka pendek adalah margin kontribusi setelah memperhitungkan biaya relevan. Ukuran ini seharusnya juga digunakan dalam menentukan komisi penjualan untuk memotivasi staf penjualan agar menjual produk yang paling menguntungkan,yaitu yang mempunyai 
margin kontribusi tertinggi”.Senada dengan pendapat Darya (2019:61), "Karena besar manfaatnya sebagai sarana perencanaan laba (provit planning device), maka margin kontribusi memiliki arti penting dalam perhitungan laba-rugi dengan metode biaya langsung (direct costing income statement)". Berikut ini disajikan grafik rencana dan volume/hasil penjualan produk Konveksi Maulidha 77 selaku obyek penelitian ini, periode Juni 2017 s.d. Mei 2018.

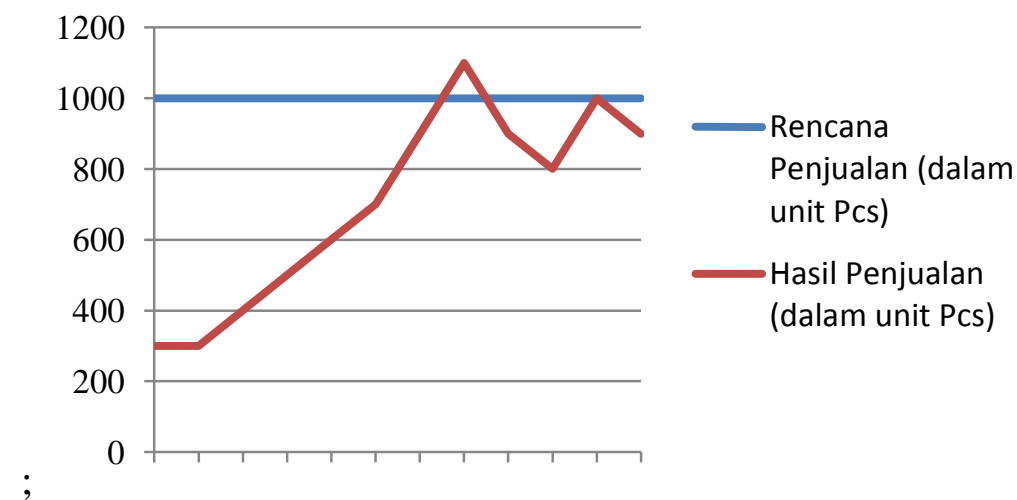

Gambar 1. Rencana dan Hasil Penjualan ProdukKonveksi Maulidha 77 (dalam Unit Pcs) Sumber: Konveksi Maulidha 77, 2018

Sedangkan hasil penjualan produk Konveksi Rockafella disajikan dalam grafik sebagai berikut:

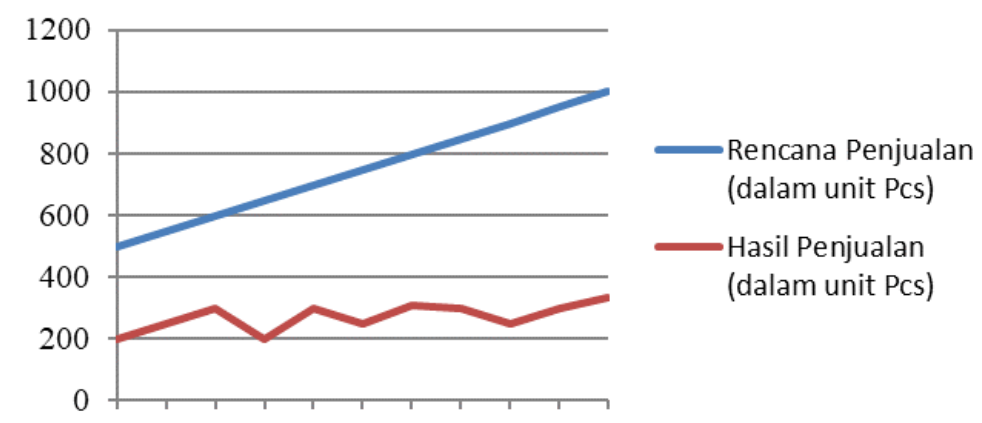

Gambar 2. Rencana dan Hasil Penjualan Produk Konveksi Rockafella (dalam Unit Pcs) Sumber: Konveksi Rockafella, 2018

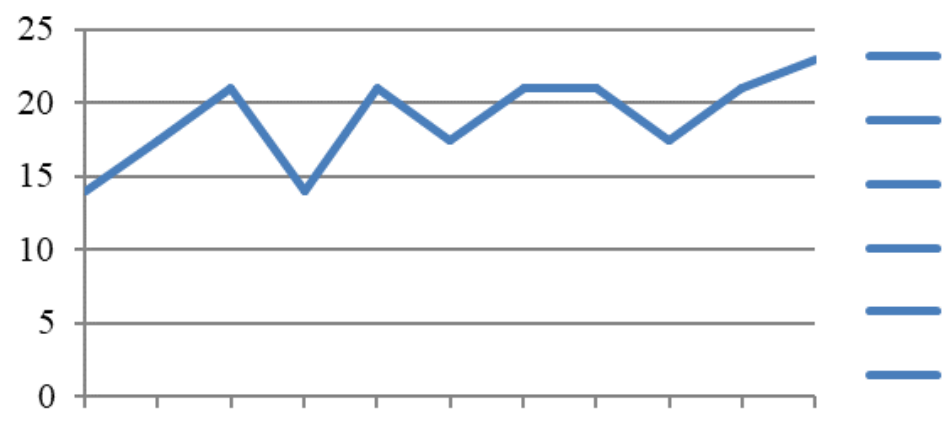

Gambar 3. Hasil Penjualan Produk Konveksi Rockafella (dalam Jutaan Rupiah) Sumber: Konveksi Rockafe 
Berdasarkan gambar di atas, terlihat bahwa hasil penjualan produk UKM Konveksi Maulidha 77 dan Rockafella bergerak fluktuatif. Sementara itu, volume/hasil penjualan akan mempengaruhi profitabilitas atau tingkat kontribusi bauran pemasaran produk terhadap perolehan laba. Melalui kegiatan analisis profitabilitas produk, diharapkan pemilik konveksi mampu menilai kinerja serta mengidentifikasi permasalahan pada program pemasaran yang telah ditetapkan, sehingga segera akan dilakukan perbaikan dan mengoptimalkan kontribusi produk terhadap pencapaian hasil dan laba perusahaan secara keseluruhan.

\section{Tinjauan Pustaka}

\subsection{Analisis Profitabilitas}

Analisis profitabilitas adalah penilaian yang dilakukan untuk menelaah pengaruh dari berbagai strategi dan program pemasaran terhadap kontribusi laba yang dapat diharapkan dari produk atau lini produk tertentu.Analisis semacam ini sangat penting bagi para manajer pemasaran.Sekalipun tujuan utama produk lebih ditekankan pada sasaran volume atau pertumbuhan pangsa pasar (dan bukan pada profitabilitas), para manajer tetap harus memahami besarnya profitabilitas yang dikorbankan untuk mencapai target penjualan atau pangsa pasar tertentu (Tjiptono, dkk; 2008). Selanjutnya Hermanto dan Agung (2015) mendefinisikan bahwa: Rasio profitabilitas merupakan hasil akhir bersih dari berbagai kebijakan dan keputusan dan rasio ini akan memberikan jawaban akhir tentang efektifitas manajemen perusahaan. Analisis profitabilitas juga mengukur keuntungan yang diperoleh dari modal-modal yang digunakan untuk menyebarkan operasional baik modal yang berasal dari pemilik atau modal asing (modal yang berasal dari luar misalkan modal pinjaman).

$\begin{array}{llr}\text { Harjito dan } & \text { Martono } & (2014: 60) \\ \text { menambahkan, } & \text { "Rasio profitabilitas }\end{array}$ terdiri dari dua jenis rasio yang menunjukkan laba dalam hubungannya dengan penjualan dan rasio yang menunjukkan laba dalam hubungannya dengan investasi.Kedua rasio ini secara bersama-sama menunjukkan efektivitas rasio profitabilitas dalam hubungannya antara penjualan dengan laba." Menurut Kasmir (2012:196), "Yang ingin dicapai suatu perusahaan adalah untuk memperoleh laba atau keuntungan yang maksimal. Dimana untuk mengetahui kemampuan perusahaan dalam memperoleh suatu keuntungan adalah dengan menggunakan analisis rasio profitabilitas".

\subsection{Tujuan dan Manfaat Rasio Profit- abilitas}

Tujuan dan manfaat rasio profitabilitas bagi perusahaan, maupun bagi pihak luar perusahaan menurut Kasmir (2012:197198) adalah sebagai berikut:

1. Untuk mengukur atau menghitung laba yang diperoleh perusahaan dalam satu periode tertentu.

2. Untuk menilai posisi laba perusahaan tahun sebelumnya dengan tahun sekarang.

3. Untuk menilai perkembangan laba dari waktu ke waktu.

4. Untuk menilai besarnya laba bersih sesudah pajak dengan modal sendiri.

5. Untuk mengukur produktivitas seluruh dana perusahaan yang digunakan, baik modal pinjaman maupun modal sendiri.

6. Untuk mengukur produktivitas dari seluruh dana perusahaan yang digunakan, baik modal sendiri.

7. Mengetahui besarnya tingkat laba yang diperoleh perusahaan dalam satu periode.

8. Mengetahui posisi laba perusahaan tahun sebelumnya dengan tahun sekarang.

9. Mengetahui perkembangan laba dari waktu ke waktu. 
10. Mengetahui besarnya laba bersih sesudah pajak dengan modal sendiri.

11. Mengetahui produktivitas dari seluruh dana perusahaan yang digunakan, baik modal pinjaman maupun modal sendiri.

\subsection{Faktor-faktor yang dipertimbang- kan dalam Tahap Analisis Profitabi- litas Produk}

Beberapa hal yang perlu dipertimbangkan dalam tahap analisis profitabilitas produk menurut Tjiptono, dkk (2008):

\section{Laporan laba/rugi konvensional} cenderung akan memberikan gambaran yang cukup memuaskan bagi perusahaan yang akan menghasilkan satu macam produk. Bagi pemanufaktur, harga pokok penjualan dalam laporan laba/rugi biasanya meliputi elemen biaya tetap dan biaya variabel, dimana setiap unit penjualan dibebani sebagian biaya tetap selain biaya variabel. Jika perusahaan tergolong multiproduk, biasanya para manajer akan lebih tertarik untuk menganalisis profitabilitas dari setiap produk yang ada. Oleh karena itu, perlu terlebih dahulu dipilah biaya menjadi dua jenis, yaitu biaya variabel dan biaya tetap.

\section{a. Biaya variable}

Biaya variabel adalah biaya-biaya yang berubah sesuai dengan perubahan volume penjualan. Contoh biaya variabel antara lain: biaya bahan baku, biaya tenaga kerja, biaya pengemasan, atau komisi penjualan, yang bertambah secara proporsional sesuai dengan peningkatan volume penjualan.

\section{b. Biaya tetap}

Biaya tetap adalah biaya-biaya yang jumlahnya tetap, tanpa memperhatikan tingkat volumenya (sejauh tidak dibutuhkan tambahan fasilitas produksi atau karyawan administratif).Kendati sebagian biaya tetap dapat diubah oleh pihak manajemen (misalnya anggaran periklanan dan gaji wiraniaga), namun biaya-biaya semacam itu tidak berubah secara otomatis mengikuti perubahan volume penjualan. Biaya tetap dibagi lagi menjadi:

a) Biaya tetap langsung

Biaya tetap langsung adalah biaya tetap yang terkait dan dapat dibebankan pada produk atau jasa spesifik, contohnya iklan produk spesifik.

b) Biaya tetap tidak langsung

Biaya tetap tidak langsung adalah biaya tetap yang dikeluarkan untuk mendukung bisnis secara keseluruhan, contohnya periklanan institusional. Biaya tetap tidak langsung masih dapat dibagi lagi menjadi:

\section{a. Traceable cost}

Traceable cost adalah biaya tetap tidak langsung yang dapat dialokasikan pada berbagai produk atas dasar tertentu yang sifatnya tidak arbitrary. Contohnya, jika seorang wiraniaga biasanya menjual dua atau lebih produk tersebut atas dasar beberapa faktor seperti persentase waktu penjualan yang dicurahkan untuk masing-masing produk.

\section{b. Non-traceable cost}

Non-traceable cost adalah biaya tetap tidak langsung yang sulit dialokasikan secara obyektif pada masing-masing produk. Contohnya, periklanan institusional dan biaya overhead umum dan administrasi.

2. Dengan memisahkan biaya tetap dan biaya variabel, manajer dapat menghitung persentase marjin kontribusi variabel atau Percentage Variable Contribution Margin (PVCM), dengan rumus sebagai berikut: 


$$
P V C M=\frac{\text { marginkontribusivariabel }}{\text { penjualandalamrupiah }}
$$

Ukuran yang dipergunakan untuk masingmasing produk, bukan lagi laba bersih operasi, melainkanan kontribusi total (total contribution). Kontribusi total merupakan jumlah yang disumbangkan oleh produk atau jasa individual bagi penutupan non-traceable indirect costs dan laba (Garrison et.al, 2006) menambahkan, "Contribution Margin adalah jumlah yang tersisa dari pendapatan dikurangi biaya variabel yang merupakan jumlah yang akan menutupi biaya tetap dan kemudian nantinya akan menjadi laba". Berikut diilustrasikan kerangka berpikir dari penelitian ini.

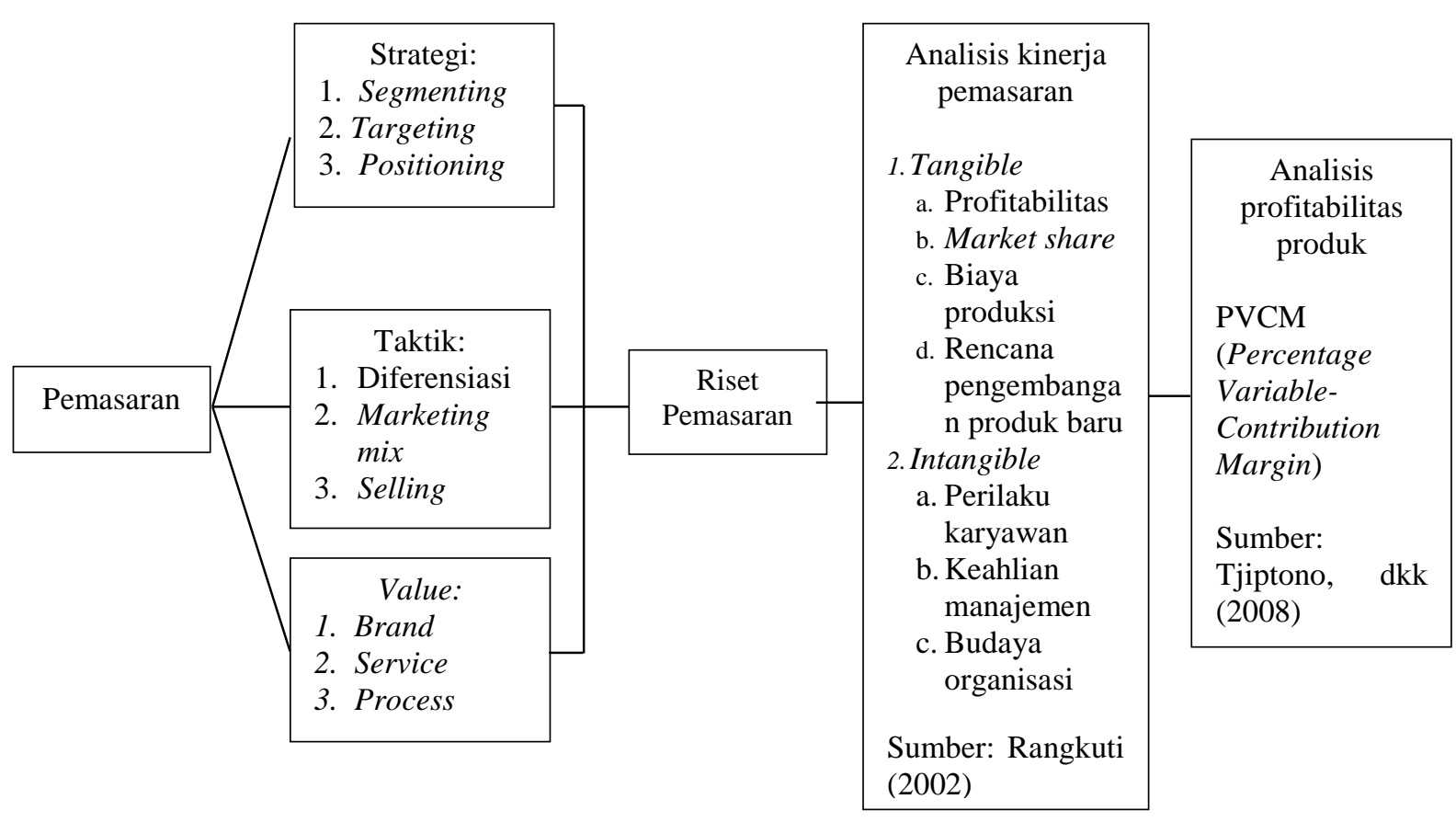

Gambar 4. Kerangka Pemikiran 


\section{Metode Penelitian}

Metode yang digunakan dalam penelitian ini adalah kualitatif dengan menetapkan fokus guna mempertajam penelitian. Fokus itu merupakan domain tunggal atau beberapa domain yang terkait dengan situasi sosial. Adapun informasi yang diperoleh selama proses penelitian ini adalah laporan keuangan, laporan margin kontribusi produk, dan data kontribusi per lini produk UKM konveksi Maulidha 77 dan Rockafella tahun 2018.

Penelitian ini menggunakan sumber primer (wawancara dengan pemilik konveksi) serta sekunder (laporan keuangan, data rencana dan hasil penjualan produk, laporan margin kontribusi produk, serta data kontribusi per lini produk). Sedangkan jenis data penelitiannya merupakan kombinasi kuantitatif (angka-angka volume penjualan dan laba perusahaan) serta kualitatif (gambar bagan dan grafik penjualan).

Dalam penelitian kualitatif, tidak digunakan istilah populasi, tetapi oleh Spradley (Sugiyono, 2018:443) dinamakan social situation atau situasi sosial yang terdiri dari tiga elemen, yaitu: tempat (place), pelaku (actors), dan aktivitas (activity) yang berinteraksi secara sinergis. Adapun situasi sosial dalam penelitian ini mencakup elemen tempat (konveksi Maulidha 77 dan Rockafella yang berlokasi di Desa Citalang Kabupaten Purwakarta), elemen orang/actors (pemilik UKM konveksi Maulidha 77 dan Rockafella), serta elemen aktivitas (proses menganalisis profitabilitas produk untuk mengukur kinerja pemasaran UKM konveksi). Selanjutnya hasil kajian penelitian ini akan ditransferkan ke UKM konveksi lainnya yang memiliki kesamaan dengan situasi social atau konveksi Rockafella dan Maulidha 77.

Sampel dalam penelitian kualitatif, bukan dinamakan responden, tetapi sebagai narasumber atau partisipan atau
informan(Sugiyono, 2018). Adapun sampel atau narasumber atau informan atau partisipan dari penelitian ini adalah pemilik UKM konveksi Rockafella dan Maulidha 77. Penelitian ini menggunakan teknik sampling purposive dimana sampel sumber data yang dipilih adalah pemilik UKM konveksi Rockafella dan Maulidha 77 dengan pertimbangan dianggap paling mengetahui aktivitas analisis kinerja pemasaran usahanya.

Uji validitas data penelitian ini secara umum dilakukan melalui uji confirmability dan uji kredibilitas, dimana penulis melakukan serangkaian proses pengumpulan data trianggulasi (wawancara, observasi, dokumentasi) serta diskusi dengan teman sejawat yang memiliki keahlian di bidang keilmuan manajemen keuangan dan akuntansi. Adapun teknik pengumpulan data yang dipergunakan adalah trianggulasi, yaitu menggabungkan teknik observasi partisipasi pasif, wawancara terstruktur, dan dokumen.

Kegiatan analisis data penelitian ini mencakup proses sebelum di lapangan, dimana penulis mempelajari hasil studi pendahuluan untuk memperoleh data sekunder. Sebelum penelitian ini dilakukan, penulis telah lebih dulu melakukan penelitian di obyek/lokasi yang sama mengenai rencana pemasaran/market plan UKM konveksi. Hasil penelitian yang diperoleh diantaranya adalah gambaran laporan keuangan UKM konveksi. Berdasarkan hasil tersebut, dikembangkan fokus penelitian lainnya selama berada di lokasi penelitian.

Penulis menjadikan pemilik UKM konveksi Maulidha 77 dan Rockafella sebagai informan kunci selama proses trianggulasi (observasi, wawancara, dan dokumentasi). Kemudian penulis mencatat proses analisis profitabilitas produk untuk mengukur kinerja pemasaran yang dilakukan pemilik konveksi. Selama proses trianggulasi, data kinerja pemasaran yang diperoleh terlihat 
masih sederhana dan belum rinci, sehingga baru dapat dikategorikan atau difokuskan pada pekerjaan analisis profitabilitas produk perusahaan.

Penulis memutuskan melakukan penelitian ini pada dua UKM konveksi, yaitu Maulidha 77 dan Rockafella, dikarenakan berlokasi di wilayah yang sama, yaitu Desa Citalang. Berdasarkan hasil studi pendahuluan, kedua pemilik konveksi ini seringkali menyebutkan atau membandingkan program pemasaran di antara keduanya.Hal ini tertulis dalam rencana pemasaran yang mereka buat sebagai bagian analisis pesaing. Penelitian ini dibatasi untuk mengukur profitabilitas produk UKM konveksi Maulidha 77 dan Rockafella, menggunakan rumus PVCV (Percentage Variable Contribution Margin). Menurut Tjiptono, dkk (2008:242), "PVCM menunjukkan persentase dari setiap tambahan nilai (rupiah) penjualan yang tersedia bagi perusahaan untuk menutup biaya tetap dan meningkatkan laba".

\section{Hasil dan Pembahasan}

Konveksi Rockafella didirikan oleh Bapak Jaski pada bulan Agustus 2017 melalui modal awal, termasuk gedung sejumlah Rp 100.000.000,- berasal dari modal sendiri dan dana pinjaman dari bank dimana jangka waktu pengembaliannya selama tiga tahun. Sedangkan konveksi Maulidha 77 didirikan oleh Ibu Nurmaulidha Lasmaningsih pada bulan Juni 2017 melalui modal awal sendiri, termasuk gedung sejumlah $\mathrm{Rp}$ 100.000.000,-. Kedua konveksi ini berlokasi di Desa Citalang Kecamatan Purwakarta Kabupaten Purwakarta. Adapun tahap menghitung Marjin Kontribusi Variabel Produk adalah sebagai berikut:

1. Disajikan laporan marjin kontribusi penjualan produk tahun 2018 .

2. Disajikan data kontribusi per lini produk.

3. Menghitung Marjin Kontribusi Variabel Produk dengan rumus:

$$
\text { PVCM }=\frac{\text { MarjinKontribusiVariabel }}{\text { PenjualandalamRupiah }}
$$

Berikut disajikan laporan margin kontribusi UKM Maulidha 77 tahun 2018:

Tabel 1. Laporan Marjin Kontribusi UKM Konveksi Maulidha 77 Purwakarta Tahun 2018 Sumber: Maulidha 77, 2018

\begin{tabular}{|c|c|}
\hline \multicolumn{2}{|l|}{ Penjualan } \\
\hline$\overline{\text { Penjualan }}$ & Rp 80.000.000,-- \\
\hline Harga pokok penjualan (HPP) & Rp 28.500.000,- \\
\hline Biaya penjualan variabel & Rp 11.500.000,- \\
\hline Marjin kontribusi variabel & Rp 40.000.000,- \\
\hline \multicolumn{2}{|l|}{ Biaya } \\
\hline \multicolumn{2}{|l|}{ Biaya Tetap } \\
\hline Biaya iklan & Rp 2.000.000,- \\
\hline Biaya gaji bagian penjualan & Rp 2.400.000,- \\
\hline Biaya produksi & Rp 2.000.000,- \\
\hline Biaya administrasi dan umum & Rp 12.000.000,- \\
\hline Total biaya tetap & Rp 18.400.000,- \\
\hline Laba sebelum pajak & Rp 21.600.000,- \\
\hline
\end{tabular}


Tabel 2. Data Kontribusi Per Lini Produk UKM Konveksi Maulidha 77 (dalam Jutaan Rupiah)

\begin{tabular}{|c|c|c|c|c|c|}
\hline \multirow{2}{*}{ Keterangan } & \multirow{2}{*}{$\begin{array}{c}\text { Total } \\
\text { Perusahaan }\end{array}$} & \multicolumn{4}{|c|}{ Jenis Produk } \\
\hline & & Kaos & Kemeja & Jersey & Jaket \\
\hline Penjualan & 80,000 & 30,000 & 15,000 & 10,000 & 25,000 \\
\hline HPP variabel & 28,500 & 15,000 & 7,000 & 3,500 & 3,000 \\
\hline Margin laba kotor & $\mathbf{5 1 , 5 0 0}$ & 15,000 & 8,000 & 6,500 & 22,000 \\
\hline Biaya penjualan variabel & 11,500 & - & 2,000 & 3,500 & 6,000 \\
\hline Margin kontribusi variabel & 40,000 & 15,000 & 6,000 & 3,000 & 16,000 \\
\hline \multicolumn{6}{|l|}{ Direct, traceable fixed cost } \\
\hline Gaji bagian penjualan & $\mathbf{9 , 0 0 0}$ & 4,000 & - & 3,000 & 2,000 \\
\hline Gaji perancang & 8,000 & 3,500 & - & 500 & 4,000 \\
\hline Biaya produksi tetap & 13,000 & 5,000 & 2,000 & 2,500 & 3,500 \\
\hline Periklanan lini produk spesifik & 2,000 & 500 & 500 & 500 & 500 \\
\hline Total & 32,000 & 13,000 & 2,500 & 6,500 & 10,000 \\
\hline Kontribusi total & 8,000 & 2,000 & 3,500 & $(3,500)$ & 6,000 \\
\hline \multicolumn{6}{|l|}{ Indirect, nontraceable fixed cost } \\
\hline Periklanan institusional & 2,000 & & & & \\
\hline Biaya administrasi dan umum & 12,000 & & & & \\
\hline Total & 14,000 & & & & \\
\hline Laba operasi bersih & $(6,000)$ & & & & \\
\hline
\end{tabular}

Berdasarkan tabel di atas, terlihat bahwa lini produk yang paling menguntungkan adalah jaket karena kontribusi totalnya paling besar, yaitu Rp 6.000.000,-. Jika dilihat dari volume penjualan, produk kaos lebih tinggi dibandingkan jaket.
Namun, biaya direct-traceable fixed cost, khususnya biaya gaji untuk kaos sedikit lebih tinggi dibandingkan produk jaket. Adapun perhitungan Marjin Kontribusi Variabel Produk UKM Konveksi Maulidha 77 adalah sebagai berikut:

$$
\mathrm{PVCM}=\begin{gathered}
\boldsymbol{R p 8 0 . 0 0 0 . 0 0 , -} \\
\begin{array}{r}
\text { Rp40.000.000, },- \\
\text { MarjinKontribusiVariabel }
\end{array}
\end{gathered}=50 \%
$$

Berdasarkan hasil perhitungan di atas, terlihat bahwa nilai PVCM UKM konveksi Maulidha 77 adalah sebesar 50\% dimana setiap pertambahan nilai penjualan yang ada di UKM konveksi Maulidha 77, bertujuan untuk menutupi biaya tetap dan meningkatkan laba. Dengan kata lain, rasio margin kontribusi $50 \%$ berarti sebesar 50\% dari setiap penjualan, digunakan untuk membayar biaya tetap dan memperoleh keuntungan/laba. Hal ini selaras dengan pernyataan pemilik bahwa Maulidha 77 mengharapkan keuntungan yang didapat perbulannya yaitu minimal $50 \%$ dari modal yang dikeluarkan.

Berikut ini disajikan laporan margin kontribusi UKM Rockafella tahun 2018: 
Tabel 3 .Laporan Marjin Kontribusi UKM Konveksi Rockafella Purwakarta Tahun 2018

\begin{tabular}{|c|c|}
\hline \multicolumn{2}{|l|}{ Penjualan } \\
\hline$\overline{\text { Penjualan }}$ & $\mathrm{Rp} 40.000 .000$ \\
\hline Harga pokok penjualan (HPP) & $\operatorname{Rp} 28.000 .000$ \\
\hline Biaya penjualan variabel & $\mathrm{Rp} \quad 480.000$ \\
\hline Marjin kontribusi variabel & Rp 11.520.000, \\
\hline \multicolumn{2}{|l|}{ Biaya } \\
\hline \multicolumn{2}{|l|}{ Biaya Tetap } \\
\hline Biaya iklan & Rp 200.000,- \\
\hline Biaya gaji pegawai & Rp 2.400.000,- \\
\hline Biaya produksi & Rp 3.000.000,- \\
\hline Biaya administrasi dan reparasi & $\operatorname{Rp} \quad 210.000,-$ \\
\hline Total biaya tetap & Rp 5.810.000,- \\
\hline Laba sebelum pajak & Rp 5.710.000,- \\
\hline
\end{tabular}

Berikut ini disajikan data kontribusi per lini produk UKM Rockafella:

Tabel 4. Data Kontribusi Per Lini Produk UKM Konveksi Rockafella (dalam Jutaan Rupiah) Sumber: Rockafella, 2018

\begin{tabular}{llll}
\hline \multirow{2}{*}{ Keterangan } & Total & \multicolumn{2}{l}{ Jenis Produk } \\
\cline { 2 - 4 } & Perusahaan & Kaos & Kemeja \\
\hline Penjualan & $\mathbf{4 0 , 0 0 0}$ & 30,000 & 10,000 \\
\hline HPP variabel & $\mathbf{2 8 , 0 0 0}$ & 16,800 & 11,200 \\
\hline Margin laba kotor & $\mathbf{1 2 , 0 0 0}$ & 9,000 & 3,000 \\
\hline Biaya variabel lain-lain & $\mathbf{4 8 0}$ & 360 & 120 \\
\hline Margin kontribusi variabel & $\mathbf{1 1 , 5 2 0}$ & 8,640 & 2,880 \\
\hline Direct, traceable fixed cost & & & \\
\hline Gaji karyawan & $\mathbf{2 , 4 0 0}$ & & 1,250 \\
\hline Biaya produksi tetap & $\mathbf{3 , 0 0 0}$ & 1,750 & $\mathbf{1 , 2 5 0}$ \\
\hline Total & $\mathbf{5 , 4 0 0}$ & $\mathbf{1 , 7 5 0}$ & $\mathbf{1 , 6 3 0}$ \\
\hline Kontribusi total & $\mathbf{6 , 1 2 0}$ & $\mathbf{6 , 8 9 0}$ & \\
\hline Indirect, nontraceable fixed cost & & & \\
\hline Biaya administrasi dan umum & 210 & & \\
\hline Total & $\mathbf{2 1 0}$ & & \\
\hline Laba operasi bersih & $\mathbf{5 , 9 1 0}$ & & \\
\hline & & & \\
\hline
\end{tabular}

Berdasarkan tabel di atas, terlihat bahwa lini produk yang paling menguntungkan adalah kaos karena kontribusi totalnya paling besar, yaitu Rp 6.890.000,-. Jika dilihat dari volume penjualan, produk kaos pun lebih tinggi dibandingkan kemeja walaupun biaya direct-traceable fixed cost, khususnya biaya produksi untuk kaos, sedikit lebih tinggi dibandingkan produk kemeja.

Adapun perhitungan Marjin Kontribusi Variabel Produk UKM Konveksi Rockafella adalah sebagai berikut: 


$$
\mathrm{PVCM}=\begin{gathered}
\text { Rp80.000.00, }- \\
\frac{\text { Rp11.520.000, }--}{\text { MarjinKontribusiVariabel }}
\end{gathered}=28,8
$$

Berdasarkan hasil perhitungan di atas, terlihat bahwa nilai PVCM UKM Rockafella adalah sebesar $28,8 \%$ dimana setiap pertambahan nilai penjualan yang ada di UKM konveksi Rockafella, bertujuan untuk menutupi biaya tetap dan meningkatkan laba. Dengan kata lain, rasio margin kontribusi $28,8 \%$ berarti sebesar $28,8 \%$ dari setiap penjualan, digunakan untuk membayar biaya tetap dan memperoleh keuntungan/laba. Hal ini selaras dengan pernyataan pemilik bahwa Rockafella menargetkan sekitar 30\% dari keuntungan yang didapatkan dari laba kotor.

Berdasarkan perhitungan di atas, terlihat bahwa rasio margin kontribusi (PVCM) Maulidha 77 lebih besar dibandingkan Rockafella. Faktor-faktor yang mempengaruhi perbedaan nilai rasio tersebut diantaranya adalah volume penjualan.Selama satu tahun ke belakang (Juni 2017 s.d. Mei 2018), total volume penjualan seluruh produk Maulidha 77, yaitu 8.400 pcs, lebih besar dibandingkan total volume penjualan seluruh produk Rockafella, yaitu 2.993 pcs.Selain itu, dipengaruhi faktor modal sendiri. Pemilik Rockafella menyediakan modal awal $\mathrm{Rp}$ 100.000.000,- termasuk gedung, berasal dari modal sendiri dan dana pinjaman dari bank dimana jangka waktu pengembaliannya selama tiga tahun, sehingga Rockafella berkewajiban mengembalikan dana pinjaman dari bank. Sedangkan Maulidha 77 Konveksi dan Sablon didirikan pada tanggal 1 Juni 2017 oleh Ibu Nurmaulidha Lasmaningsih melalui modal awal sendiri, termasuk gedung sejumlah Rp 100.000.000,Sedangkan konveksi Maulidha 77 didirikan melalui modal awal sendiri, termasuk gedung, sejumlah $\mathrm{Rp}$ 100.000.000,-.
Berdasarkan hasil pengumpulan data, terlihat persamaan dan perbedaan profil usaha antara Maulidha 77 dan Rockafella.Kedua usaha konveksi ini sama-sama berdiri pada tahun 2017 dan berlokasi di desa Citalang Kecamatan Purwakarta Kabupaten Purwakarta. Keduanya memiliki kapasitas produksi yang sama, yaitu 100 pcs per karyawan per hari, setara dengan 2000 pcs dalam satu bulan. Keduanya memiliki daerah pemasaran yang relatif sama, yaitu Purwakarta, Cikampek, Subang, dan Karawang. Bahkan pemasaran produk Maulidha 77 sudah merambah ke luar Pulau Jawa, yaitu Lombok dan Padang. Keduanya biasanya membeli bahan baku langsung hanya pada saat ada pesanan saja, sehingga tidak terjadi penumpukan bahan atau material di gudang. Keduanya menetapkan syarat pembelian yang sama kepada konsumen, yakni membayar terlebih dahulu biaya muka (down payment/DP) sebesar 50\%. Harga produk yang ditetapkan hampir sama dengan pesaing dan disesuaikan dengan kualitas bahan. Fasilitas dan mesin yang dimiliki kedua konveksi ini relatif sama, meliputi: mesin jahit, mesin obras, mesin overdeck, mesin rantai, mesin janome, mesin press kaos, meja sablon, dan mesin kancing. Bahkan Maulidha 77 menambahkan printer serta komputer untuk mendesain. Keduanya memanfaatkan media sosial untuk aktivitas promosi produk. Bahkan Maulidha 77 menambahkan dengan kartu nama dan testimosi positif dari pelanggan. Rata-rata pembeli kedua konveksi ini adalah 10 orang per bulan. Sedangkan perbedaan di antara keduanya, disajikan melalui tabel berikut ini: 
Tabel 5. Perbedaan Profil Konveksi Rockafella dan Maulidha 77

\begin{tabular}{|c|c|c|c|}
\hline Keterangan & Rockafella & Maulidha 77 & Keterangan \\
\hline $\begin{array}{l}\text { Jumlah } \\
\text { karyawan }\end{array}$ & 4 orang & 9 orang & \\
\hline Visi dan Misi & $\begin{array}{l}\text { Menciptakan produk yang } \\
\text { berkualitas. }\end{array}$ & $\begin{array}{l}\text { Mengarah pada nilai ibadah } \\
\text { untuk membuka lapangan } \\
\text { kerja. }\end{array}$ & \\
\hline Status hokum & $\begin{array}{l}\text { Belum terdaftar secara } \\
\text { hukum }\end{array}$ & Sudah memiliki SIUP & \\
\hline $\begin{array}{l}\text { Struktur } \\
\text { organisasi }\end{array}$ & $\begin{array}{l}\text { Terdiri dari: pemilik, } \\
\text { penjahit, finishing, dan } \\
\text { penyablon. }\end{array}$ & $\begin{array}{l}\text { Terdiri dari: pemilik, } \\
\text { sekretaris, administrasi, } \\
\text { cutting, jahit dan obras, } \\
\text { sablon dan desain, serta } \\
\text { bagian pengiriman. }\end{array}$ & $\begin{array}{l}\text { Struktur organisasi Maulidha } 77 \\
\text { lebih spesifik. }\end{array}$ \\
\hline Keterangan & Rockafella & Maulidha 77 & Keterangan \\
\hline Lini produk & $\begin{array}{l}\text { 1. Kaos polos, kaos } \\
\text { komunitas, kaos promosi, } \\
\text { kaos olahraga sekolah, } \\
\text { kaos sablon, kaos } \\
\text { bola/futsal. } \\
\text { 2. Kemeja } \\
\text { 3. Jaket motor dan jaket } \\
\text { formal } \\
\text { 4. Sweater/Hodie } \\
\text { 5. Seragam kerja } \\
\text { 6. Polo shirt } \\
\text { 7. Seragam sekolah } \\
\text { 8. Baju olahraga } \\
\text { 9. Sablon }\end{array}$ & $\begin{array}{l}\text { 1. Kaos pantai, kaos polos, } \\
\text { kaos komunitas, kaos } \\
\text { polo, kaos sablon, kaos } \\
\text { tim. } \\
\text { 2. Kemeja drill, kemeja } \\
\text { katun, kemeja lengan } \\
\text { panjang dan kemeja } \\
\text { lengan pendek. } \\
\text { 3. Jaket taslan dan jaket } \\
\text { mayer. } \\
\text { 4. Sweater } \\
\text { 5. Sablon }\end{array}$ & $\begin{array}{l}\text { Lini produk Rockafella lebih } \\
\text { luas dengan tambahan produk } \\
\text { kemeja, polo shirt, dan seragam } \\
\text { sekolah. }\end{array}$ \\
\hline Harga produk & & & $\begin{array}{l}\text { Harga kaos tim dan kaos } \\
\text { komunitas di Maulidha } 77 \text { lebih } \\
\text { tinggi dibandingkan harga } \\
\text { produk serupa di Rockafella. } \\
\text { Harga jaket, sweater, polo } \\
\text { shirt, dan baju } \\
\text { olahragaRockafella lebih tinggi. }\end{array}$ \\
\hline Merek & $\begin{array}{l}\text { Menggunakan label merek } \\
\text { sendiri, dengan nama } \\
\text { "rockafella" yang terpasang } \\
\text { pada bagian kerah baju. }\end{array}$ & $\begin{array}{l}\text { Belum mempunyai label } \\
\text { khusus pada kemasan } \\
\text { maupun pakaian yang } \\
\text { diproduksinya. } \\
\end{array}$ & \\
\hline Pola jahit & & & $\begin{array}{l}\text { Rockafella menetapkan pola } \\
\text { jahit dengan jarum 3, sehingga } \\
\text { memperkuat benang jahitan agar } \\
\text { tidak mudah lepas. }\end{array}$ \\
\hline $\begin{array}{l}\text { Program } \\
\text { promosi } \\
\text { penjualan }\end{array}$ & $\begin{array}{l}\text { Memberikan } 1 \text { produk free } \\
\text { kepada pelanggan yang } \\
\text { membeli produk minimal } 50 \\
\text { pcs dan } 2 \text { produk free jika } \\
\text { membeli minimal } 100 \text { pcs. }\end{array}$ & $\begin{array}{l}\text { Memberikan harga yang } \\
\text { telah ditetapkan, bahkan } \\
\text { mereka juga akan } \\
\text { memberikan bonus, seperti } \\
\text { kaus, sticker, ataupun } \\
\text { spanduk. }\end{array}$ & \\
\hline
\end{tabular}




\section{Kesimpulan}

Berdasarkan hasil pengolahan dan analisa data yang telah dikemukakan sebelumnya, maka penulis menarik kesimpulan sebagai berikut:

\section{Kinerja pemasaran UKM konveksi} Rockafella berdasarkan tingkat profitabilitas produk melalui nilai PVCM adalah sebesar $28,8 \%$ dimana setiap pertambahan nilai penjualan yang ada di Rockafella, bertujuan untuk menutupi biaya tetap dan meningkatkan laba. Nilai rasio margin kontribusi tersebut berarti sebesar $28,8 \%$ dari setiap penjualan, digunakan untuk membayar biaya tetap dan memperoleh keuntungan/ laba. Angka rasio margin kontribusi sebesar 28,8\% juga menunjukkan bahwa dana yang tersedia sejumlah $\mathrm{Rp}$ 11.520.000,digunakan untuk membayar biaya tetap dan memperoleh laba atau keuntungan. Margin kontribusi tersebut dijadikan salah satu cara membantu Rockafella dalam keputusan produksi dan penetapan harga suatu produk. Hal tersebut selaras dengan keinginan pemilik Rockafella yang menetapkan target $30 \%$ dari keuntungan yang didapatkan dari laba kotor. Angka margin kontribusi sebesar $28,8 \%$ dapat pula menunjukkan kemampuan Rockafella dalam menghasilkan laba dan pendapatan usaha serta mening-katkan ke level bisnis selanjutnya, baik dari sisi volume penjualan maupun peningkatan aktiva atau modal sendiri.

\section{Kinerja pemasaran UKM konveksi} Maulidha 77 berdasarkan tingkat profitabilitas produk melalui nilai PVCM adalah sebesar $50 \%$ dimana setiap pertambahan nilai penjualan yang ada di Maulidha 77, bertujuan untuk menutupi biaya tetap dan meningkatkan laba. Nilai rasio margin kontribusi tersebut berarti sebesar $50 \%$ dari setiap penjualan, digunakan untuk membayar biaya tetap dan memperoleh keuntungan/laba. Angka rasio margin kontribusi sebesar 50\% juga menunjukkan bahwa dana yang tersedia sejumlah Rp 40.000.000,- digunakan untuk membayar biaya tetap dan memperoleh laba atau keuntungan. Margin kontribusi tersebut dijadikan salah satu cara membantu Maulidha 77 dalam keputusan produksi dan penetapan harga suatu produk. Hal tersebut selaras dengan keinginan pemilik Maulidha 77 yang menetapkan target $50 \%$ dari modal yang dikeluarkan. Angka margin kontribusi sebesar 50\% dapat pula menunjukkan kemampuan Maulidha 77 dalam menghasilkan laba dan pendapatan usaha serta meningkatkan ke level bisnis selanjutnya, baik dari sisi volume penjualan maupun peningkatan modal atau aktiva.

3. Kondisi profitabilitas produk melalui nilai PVCM UKM konveksi Maulidha 77 lebih besar dibandingkan UKM konveksi Rockafella. Faktor-faktor yang mempengaruhi perbedaan tersebut dilihat dari aspek keuangan adalah volume penjualan, modal sendiri, dan aktiva. Maulidha 77 memiliki volume penjualan sebesar 8400 unit produk, sedangkan Rockafella memiliki volume penjualan sebesar 2.993 unit produk. Maulidha 77 menyediakan modal sendiri sebesar $\mathrm{Rp}$ 100.000.000,- sedangkan Rockafella menyediakan modal sebesar $\mathrm{Rp}$ 100.000.000,- yang berasal dari modal sendiri dan pinjaman dana pihak ketiga. Adapun faktor-faktor yang mempengaruhi perbedaan nilai PVCM, dilihat dari aspek pemasaran adalah bauran pemasarannya, meliputi: lini dan kualitas produk, harga, 
distribusi, promosi, fasilitas, dan layanan.

Bauran pemasaran tersebut dapat mempengaruhi peningkatan volume penjualan.

Berdasarkan hasil pengolahan dan analisa data, sebagai saran untuk meningkatkan profitabilitas produk dan pengembangan program pemasaran, maka diperlukan upaya sebagai berikut:

1. Saran bagi pemilik konveksi Rockafella bahwa berdasarkan aspek keuangan, sekiranya terlebih dahulu menyelesaikan kewajiban pinjaman dana pihak ketiga, sehingga selanjutnya mampu fokus dalam peningkatan volume penjualan, permodalan, dan peningkatan aktiva (aset tetap maupun aset lancar). Adapun berdasarkan aspek pemasaran, sekiranya senantiasa meningkatkan program bauran pemasaran, meliputi: penyesuaian kebijakan harga produk, variasi lini dan kualitas produk, distribusi yang lebih luas, bauran promosi yang lebih beragam, fasilitas, layanan, serta mengembangkan kemitraan dan program manajemen hubungan pelanggan. Selain itu, sekiranya senantiasa melakukan evaluasi kinerja pemasaran, diantaranya menggunakan ukuran PVCM ini, sehingga mampu menganalisis produk mana yang paling menguntungkan, ketepatan penentuan harga, serta produk mana yang seharusnya dipromosikan dan diiklankan paling optimal.

2. Saran bagi pemilik konveksi Maulidha 77 bahwa berdasarkan aspek keuangan, sekiranya mampu menekan biaya tetap, sehingga dapat meningkatkan laba atau keuntungan, yang dapat dialokasikan untuk permodalan dan aktiva (aset tetap maupun aset lancar). Adapun berdasarkan aspek pemasaran, sekiranya senantiasa meningkatkan program bauran pemasaran, meliputi: penguatan positioning merek, penyesuaian kebijakan harga produk, variasi lini dan kualitas produk, distribusi yang lebih luas, bauran promosi yang lebih beragam, fasilitas, layanan, serta mengembangkan kemitraan dan program manajemen hubungan pelanggan. Selain itu, sekiranya senantiasa melakukan evaluasi kinerja pemasaran, diantaranya menggunakan ukuran PVCM ini, sehingga mampu menganalisis produk mana yang paling menguntungkan, ketepatan penen-tuan harga, serta produk mana yang seharusnya dipromosikan dan diiklankan paling optimal.

3. Penelitian ini belum secara lengkap menyajikan data kontribusi per lini produk, bahkan hingga ke unit bisnis lainnya, yaitu percetakan dan sablon. Penulis dalam penelitian ini pun belum secara mendalam menganalisa profitabilitas produk khususnya dan profitabilitas bisnis pada umumnya, dengan menggunakan berbagai ukuran untuk mengevaluasi kinerja pemasaran konveksi, sehingga memerlukan penelitian lebih lanjut. Ukuran yang dimaksud di antaranya: profit margin, ROI, ROVA, Return on Equity, Growth Ratio, market share, serta nonfinancial metrics. Selanjutnya diperlukan pula penelitian mengenai analisis produktivitas untuk menilai konsekuensi penjualan atau pangsa pasar yang dihasilkan dari penerapan strategi pemasaran tertentu. Analisis ini berkaitan dengan estimasi hubungan antara harga atau pengeluaran pemasaran lainnya (seperti anggaran periklanan) dan volume penjualan atau pangsa pasar produk atau lini produk spesifik.

\section{Daftar Pustaka}

Blocher, C. \& Cokins, L. (2007). Manajemen biaya penekanan strategis. Jakarta: Salemba Empat.

Cannon, P. J., Perreault, W. D. \& McCarthy, J. E. (2009). Pemasaran dasar pendekatan manajerial 
global. (16 ${ }^{\text {th }}$ Ed). Jakarta: Salemba Empat.

Darya, I G. P. (2019). Akuntansi manajemen. Ponorogo: Uwais Inspirasi Indonesia.

Dinas KUMKM targetkan 20.000 wirausahawan baru. 21 Februari 2017. Tersedia: jabar.tribunnews .com.

Gambaran singkat bisnis konveksi. (2 September 2018). Tersedia: https://www.kerjausaha.com/2012/ 09/gambaran-singkat-bisnis konveksi. html

Garrison, H. R., Eric, W. N. \& Peter, C. B. (2006). Akuntansi manajerial. (terjemahan: A. Totok Budisantoso). Buku I. $11^{\text {th }}$ Ed. Jakarta: Salemba Empat.

Harjito, A. \& Martono. (2014). Manajemen keuangan. Yogyakarta: Ekonisia.

Hermanto, B. \& Mulyo A. (2015). Analisa laporan keuangan. Jakarta: Lentera Ilmu Cendekia.

Kasmir. (2012). Analisa laporan keuangan. Jakarta: Rajawali Pers. Lasmaningsih, N. (2018). Wawancara mengenai analisis kinerja pemasaran di Desa Citalang Purwakarta.

Nurhayani \& Deni, S. (2019). Strategi pemasaran kontemporer. Serang: Qiara Media Partner.

Pearce, J. A. \& Richard, B. R. (2008). Manajemen strategis formulasi implementasi dan pengendalian. Jakarta: Salemba Empat.

Sugiyono. (2018). Metode penelitian bisnis pendekatan kuantitatif, kualitatif, kombinasi, dan $R \& D$. Bandung: Alfabeta.

Tjiptono, et al. (2008). Pemasaran strategik. Yogyakarta: Andi 